\title{
Sucessfull management of bilateral presumed Candida endogenous endophtalmitis following pancreatitis
}

\section{Tratamento bem sucedido de caso de endoftalmite endógena bilateral presumida por Candida pós pancreatite}

Ricardo Evangelista Marrocos de Aragão ${ }^{1}$, leda Maria Alexandre Barreira ${ }^{2}$, Francisco Holanda Oliveira Neto ${ }^{1}$, Felipe de Freitas Beserra ${ }^{1}$, Cesar Pereira de Araujo' ${ }^{1}$, Carine Soares Ramos do Nascimento ${ }^{1}$

\begin{abstract}
Endogenous endophthalmitis is a rare, and frequently devastating, ophthalmic disease. It occurs mostly in immunocompromised patients, or those with diabetes mellitus, cancer or intravenous drugs users. Candida infection is the most common cause of endogenous endophthalmitis. Ocular candidiasis develops within days to weeks of fungemia. The association of treatment for pancreatitis with endophthalmitis is unusual. Treatment with broad-spectrum antibiotics and total parenteral nutrition may explain endogenous endophthalmitis. We report the case of a patient with pancreatitis treated with broad-spectrum antibiotics and total parenteral nutrition who developed bilateral presumed Candida endogenous endophthalmitis that was successfully treated with vitrectomy and intravitreal amphotericin $B$.
\end{abstract}

Keywords: Amphotericin B/therapeutic use; Candida; Endophthalmitis; Pancreatitis; Uveitis

RESUMO

Endoftalmite endógena é uma condição oftalmológica rara e frequentemente devastadora. Ocorre principalmente em pacientes imunocomprometidos, diabéticos, com neoplasias ou usuários de drogas intravenosas. Infecção por Candida é a causa mais comum de endoftalmite endógena. A candidíase ocular ocorre de dias a semanas após a fungemia. A associação de endoftalmite e o tratamento para pancreatite é rara. O tratamento com antibióticos de amplo espectro e alimentação parenteral total podem explicar uma endoftalmite endógena. Neste estudo, reportamos o caso de um paciente com pancreatite tratado com antibióticos de amplo espectro e alimentação parenteral total que desenvolveu endoftalmite endógena bilateral presumida por Candida que foi tratado com sucesso com vitrectomia e injeção intravítrea de amfotericina B.

Descritores: Amfotericina B/uso terapêutico; Candida; Endoftalmite; Pancreatite; Uveite

${ }^{1}$ Serviço de Oftalmologia do Hospital Universitário Walter Cantidio da Universidade Federal do Ceara, Fortaleza (CE), Brasil. ${ }^{2}$ Centro Integrado de Diabetes e Hipertensão do Estado do Ceará, Fortaleza (CE), Brasil.

The authors declare no conflicts of interests.

Received for publication 26/12/2014 - Accepted for publication 11/07/2015 


\section{INTRODUCTION}

$\mathbf{E}$ ndogenous fungal endophthalmitis (EFE) is a rare, sightthreating, and frequently devastating condition caused commonly by Candida species through hematogenous dissemination and usually occurs in patients with chronic diseases such as diabetes mellitus, systemic malignancy, extensive gastrointestinal surgery, or patients under systemic immunomodulatory therapy and chemotherapy. It develops within three days and involves at least two weeks of fungemia. Endogenous fungal endophthalmitis (EFE) develops slowly in focal or multifocal areas of chorioretinitis. Either granulomatous or nongranulomatous inflammation is observed with keratic precipitates, hypopyon, and vitritis with cellular aggregates. ${ }^{(1)}$ We report a case of bilateral endogenous endophthalmitis secondary to pancreatitis. The patient was managed successfully with vitrectomy, intravenous, and intravitreal administration of amphotericin B.

\section{CASE Report}

A 35-year-old man requested medical care as a result of a three-week history of blurred vision, floaters, pain and conjunctival injection in both eyes (OU). Tracing his history, he had been treated for pancreatitis over a two-month period. He had an indwelling double lumen subclavian catheter and was receiving broad-spectrum antibiotics and parenteral nutrition during his hospitalization time. He had no ocular history of disease, trauma or prior surgeries.

On ophthalmic examination, the best-corrected visual acuity was 20/60 in the right eye and 20/40 in the left. Intraocular pressure (IOP) as measured by a Goldmann aplanation tonometer was $19 \mathrm{mmHg}$ in the right eye and $15 \mathrm{mmHg}$ in the left. On the slit-lamp examination light conjuntival hyperemia was observed, with anterior chamber cells +2 in the right eye and +1 in the left. Vitreal inflammatory cells was also observed, $1+$ in the right and +0.5 in the left. Fundus examination revealed no signs of inflammation. Fluorescein angiogram showed small areas of hyperfluorescence in the macula of both eyes (Figures 1 and 2).

The patient was managed with corticosteroids topically and systemically. Two weeks later the BCVA dropped to counting fingers at $0.5 \mathrm{~m}$ in the right eye and hand motion in the left. Slitlamp examination showed marked conjunctitival hyperemia, corneal haziness, anterior chamber cells +4 in the right eye and +3 in the left, a small hypopyon was observed in OU. The fundus evaluation revealed multiple cotton-ball opacities in the vitreous and some had coalesced to a "string of beads" appearance and a clear view of the retina was not possible due to intense vitreous inflammation in OU.The clinical scene was typical of endogenous endophthalmitis most probably due to Candida species. An ultrasound B-scan was performed (Figures 3 and 4). It showed dispersed opacities within the vitreous cavity and posterior vitreous detachment in both eyes.

A 23-gauge pars plana vitrectomy was permormed (AccurusOे; Alcon, Irvine, CA) and intravitreal amphotericin-B was administered at the end of the procedure. Procedures were performed first in the left eye and, a week later, in the right eye.

Intraocular and vitreous cultures were negative, as was blood culture. Based on the clinical features, $200 \mathrm{mg}$ of oral fluconazole per day was initiated promptly and it was continued for two months.

Within a week of the vitrectomy procedures, the patient's BCVA improved to 20/80 in the right eye and 20/60 in the left eye and the media started clearing. Discrete chorioretinitis patches were observed on fundus examination. After three weeks, the media cleared completely, and the BCVA reached 20/60 and 20/ 50 in the right and left eyes respectively.

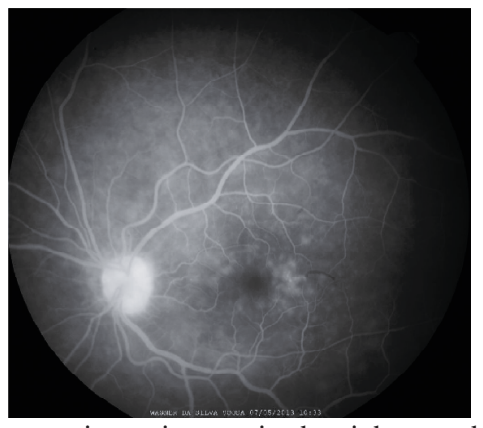

Figure 1: Fluorescein angiogram in the right eye showing areas of hyperfluorescence in the macula

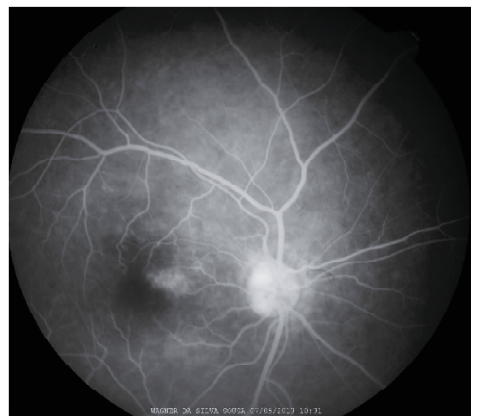

Figure 2: Fluorescein angiogram in the left eye showing small areas of hyperfluorescence in the macula

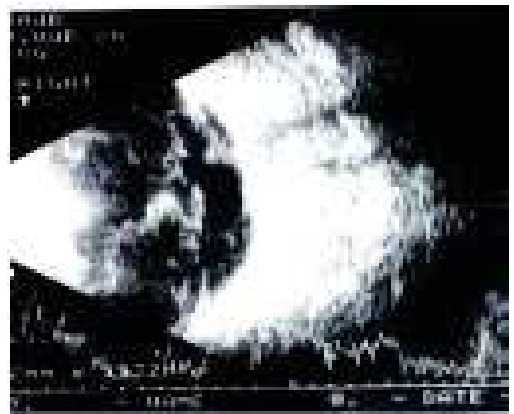

Figure 3: B-scan Ultrasound image of the right eye showing dispersed opacities within the vitreous cavity and posterior vitreous detachment

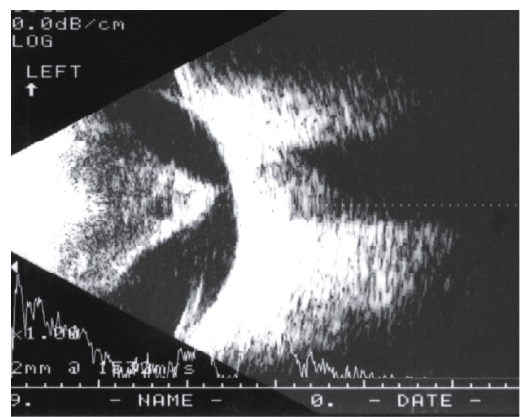

Figure 4: B-scan ultrasound image of the left eye showing dispersed opacities within the vitreous cavity and posterior vitreous detachment

\section{DISCUSSION}

Endogenous fungal endophthalmitis (EFE) is a rare form of endophthalmitis that occurs when pathogens spread across the blood and cause intraocular infection, a blood borne spread of the microorganism to the eye. ${ }^{(2,3)}$ It accounts for less than $10 \%$ of all forms of endophthalmitis. Immunocompromised patients are most 
at risk for developing EFE. Diabetes mellitus, systemic malignance, sickle cell anaemia, systemic lupus eritematosus, and human immunodeficiency virus (HIV) infection are predisposing conditions. ${ }^{(1)}$ EFE is further distinguished from exogenous endophthalmitis by occurring most in immunocompromised patients, patients receiving chemotherapy or total parenteral nutrition, or intravenous drugs abusers, and prolonged usage of indwelling catheters and antibiotics. ${ }^{(3,4)}$ Since endogenous endophthalmitis represents a metastasis from a distant focus of infection, one must consider the possibility of urinary tract infection, pneumonia, bacterial meningitis, or a liver abscess as possible sources of infection. ${ }^{(1,5)}$ It can occur at any age, and in either sex. Historically, it has carried a poor prognosis for visual recovery. ${ }^{(6)} \mathrm{EFE}$ are most commonly due to Candida, Aspergillus, and Coccidioides ${ }^{(1)} \mathrm{EFE}$ develops slowly as focal or multifocal areas of chorioretinitis. Either granulomatous or non-granulomatous inflammation is observed with anterior chamber inflammation manifested by the presence of a hypopyon, keratic precipitates, and vitritis with cellular aggregates. ${ }^{(1,3)}$ The infection usually begins in the choroid, and can break through the Bruch membrane, form subretinal abscess, and secondarily into the retina and vitreous. Typically, multiple, bilateral, white, wellcircumscribed lesions, with overlying vitreous inflammation, characterize Candida chorioretinitis, while vascular sheathing and intraretinal haemorrhages may be associated. The vitreous exudates may display a typical "string-of-pearls" appearance. Patients complain of eye pain, and may have blurred vision or spots in their fields of vision. Patients with EFE may have a positive blood culture, prior eye symptoms or signs. Candida endophthalmitis occurs in up to $37 \%$ of patients with candidemia if not in antifungal therapy. ${ }^{(1)}$ It is not known why the eye is a common end organ target of fungemia. Candida albicans is believed to have a tropism for the eye. ${ }^{(3)}$ The pathogenesis of candidemia remains unknown but is likely multifactorial, including the use of broad-spectrum antibiotics, the presence of central venous catheters, administration of total parenteral nutrition, abdominal surgery, neutropenia, and conditions discussed previously. The differential diagnosis of Candida endophthalmitis includes toxoplasmic retinochoroiditis, which exhibits posterior pole lesions that can appear yellow-white with fluffy borders and range in size from small cotton-wool spots to the width of several discs in diameter.

Citomegalovirus retinitis, coccidioidomycotic choroiditis and endophthaslmitis are caused by others funguses such as Aspergillus, Cryptococcosis, and bacterial endophthalmitis. ${ }^{(1)}$ Candida vitreous snowball lesions may also resemble parsplanitis. ${ }^{(1)}$ In most cases, the diagnosis of ocular candidiasis is mainly dependent on the typical ocular clinical appearance with anterior chamber inflammation, chorioretinal lesions distributed throughout the postequatorial fundus and vitreous exudates, typically with the appearance of a "strings-ofpearls". (7) The classic treatment of EFE is antifungal agents systemically and locally. Because the eye is a protected compartment, penetration of systemically administered antifungal agents is highly variable. In the posterior segment of the eye, amphotericin $B$ achieves very poor concentrations, while fluconazole contractions are high. Among newer antifungal agents, voriconazole shows the most promise, because therapeutic concentrations for most Candida and Aspergillus species are achieved in the vitreous and broad antifungal activity. ${ }^{(8,9)}$ Vitrectomy is recommended for sight-threatening endophthalmitis. ${ }^{(10)}$ Sampling the vitreous at the time of vitrectomy provides important culture data to guide treatment, although the culture may be negative in some cases. Removing localized areas of infection that would not respond to systemic antifungal agents decreases the overall burden of organism. The vitrectomy is usually combined with administration of intravitreal fungal agents. ${ }^{(9)} \mathrm{A}$ team approach involving both ophthalmology and infectious disease is essential to the success of treatment and preservation of visual acuity.

In this report our patient was diagnosed with bilateral endogenous endophthalmitis secondary to pancreatitis. In a review no association with the treatment of pancreatitis and endophthalmitis was found. Pancreatitis is related with sudden vision loss due to Purtscher-like retinophaty. ${ }^{(11)}$

Our patient was treated with broad-spectrum antibiotics and received total parenteral nutrition that may explain the endogenous endophthalmitis.

\section{REFERENCES}

1. Moorthy RS, Rao PK, Read RW, Van Gelder RN, Vitale AT, Bodaghi B, Parrish CM. Basic and Clinical Science Course. Intraocular inflammation and uveitis. San Francisco: American Academy of Ophthalmology; 2012-2013. p. 271-80.

2. Wu ZH, Chan RP, Luk FO, Liu DT, Chan CK, Lam DS, et al. Review of clinical features, microbiological spectrum, and treatment outcomes of endogenous endophthalmitis over an 8-year period. J Ophthalmol. 2012; 265078.

3. Step Klotz SA, Penn CC, Negvesky GJ, Butrus SI. Fungal and parasitic infections of the eye. Clin Microbiol Rev. 2000 ;13(4):662-85. Review.

4. Chang TS, Chen WC, Chen HS, Lee HW. Endogenous Candida endophthalmitis after two consecutive procedures of suction dilatation and curettage. Chang Gung Med J. 2002;25(11):778-82.

5. Kim SJ, Seo SW, Park JM, Chung IY. Bilateral endophthalmitis as the initial presentation of bacterial meningitis. Korean J Ophthalmol. 2009;23(4):321-4.

6. Connell PP, O'Neill EC, Fabinyi D, Islam FM, Buttery R, McCombe $\mathrm{M}$, et al. Endogenous endophthalmitis: 10-year experience at a tertiary referral centre. Eye (Lond). 2011;25(1):66-72.

7. Chignell AH. Endogenous candida endophthalmitis. J R Soc Med.1992; 85(12):721-4.

8. Blázquez EP. Fondo de ojo en el paciente crítico no neutropénico: endoftalmitis candidiásica. Rev Iberoam Micol. 2006; 23(1):16-9.

9. Riddell J 4th, Comer GM, Kauffman CA. Treatment of endogenous fungal endophthalmitis: focus on new antifungal agents. Clin Infect Dis. 2011;52(5):648-53.

10. Bodaghi B. [Fungal endogenous endophthalmitis]. J Fr Ophtalmol. 2011;34(1):40-5.French.

11. López-Tizón E, Reinoso-Montalvo C, Mencía-Gutiérrez E, Gutiérrez-Díaz E. [Acute pancreatitis presenting as sudden blindness]. Arch Soc Esp Oftalmol. 2006;81(3):161-3. Spanish.

\section{Corresponding author:}

Ricardo Evangelista Marrocos de Aragão

Hospital Universitário Walter Cantidio, Universidade Federal do Ceará, Fortaleza (CE), Brazil.

E-mail: ricardomarrocos@yahoo.com

\section{ERRATA}

No artigo "Sucessfull management of bilateral presumed Candida endogenous endophtalmitis following pancreatitis" dos autores: Ricardo Evangelista Marrocos de Aragão ${ }^{1}$, Ieda Maria Alexandre Barreira ${ }^{2}$, Francisco Holanda Oliveira Neto ${ }^{1}$, Felipe de Freitas Beserra ${ }^{1}$, Cesar Pereira de Araujo ${ }^{1}$, Carine Soares Ramos do Nascimento ${ }^{1}$, com número de DOI 10.5935/ 0034-7280.20160047, publicado na Revista Brasileira de Oftalmologia, volume 75, número 3, maio-junho 2016 (Rev. Bras. Oftalmol. 2016; 75 (3) 228-30); pág. 228-30, na página 228: Onde se lia:

${ }^{1}$ Setor de Patologia Ocular do Banco de Olhos, Hospital Geral de Fortaleza, Fortaleza (CE), Brasil.

${ }^{2}$ Hospital Geral de Fortaleza, Fortaleza (CE), Brasil; Fundação de Ciência e Pesquisa Maria Ione Xerez Vasconcelos; Fortaleza (CE), Brasil.

Leia-se:

${ }^{1}$ Serviço de Oftalmologia do Hospital Universitário Walter Cantidio da Universidade Federal do Ceara, Fortaleza (CE), Brasil.

${ }^{2}$ Centro Integrado de Diabetes e Hipertensão do Estado do Ceará, Fortaleza (CE), Brasil. 
